\title{
Vuorovaikutuksen monitahoisuus myyntineuvotteluissa
}

Niemi, Jarkko \& Vuori, Johanna (toim.) Myyntityö vuorovaikutuksena. Tampere, Vastapaino 2021, 294 sivua.

Myyntityö vuorovaikutuksena -teos alkaa lyhyellä, yhteistyökumppaneiden kirjoittamalla esipuheella sekä toimittajien kirjoittamalla luvulla, joka esittelee kirjan tutkimukselliset lähtökohdat. Lisäksi kirjassa on seitsemän lukua, jotka esittelevät eri tutkimuksia tuloksineen. Viimeinen luku on toimittajien yhteen vetämä "jälkisoitto", jossa he käyvät läpi kulttuurisia käsityksiä myyntityöstä opeteltavissa olevana taitona, pohtivat myynnin tutkimuksen ja käytännön myyntityön yhteyttä sekä summaavat kirjan annin. Molemmat toimittajat ovat osallistuneet myös useiden tutkimuksellisten lukujen kirjoittamiseen, ja vain kolmessa luvussa heitä ei ole ilmoitettu kirjoittajiksi. Lisäksi kirjan liitteeseen on lisätty keskustelunanalyyttiset litterointimerkinnät, jotka helpottavat aineistokatkelmien lukemista ja tulkintaa sekä analyysin seuraamista.

Teoksen ensimmäinen luku esittelee otsikkonsa mukaisesti myyntivuorovaikutuksen tutkimuksen lähtökohtia. Siinä käydään läpi aiempaa kirjallisuutta sekä niiden aiheiden että menetelmien näkökulmista ja keskitytään esittelemään keskeiset tulokset. Lisäksi esitellään kirjassa käytetyt tutkimusmenetelmät eli keskustelunanalyysi, joka on käytössä kirjan luvuista neljässä, sekä sisällönanalyysi, jota hyödynnetään kolmessa luvussa. Samassa yhteydessä esitellään myös tutkimushankkeet kirjan lukujen taustalla sekä niissä hyödynnetyt aineistot. Vain yhdessä luvussa käsitellään kuluttajamyyntiä eli yrityksen ja yksityisen asiakkaan välistä vuorovai- 
kutusta. Kaikissa muissa on kyse kahden yrityksen edustajien välisestä vuorovaikutuksesta. Jokaisen luvun alussa esitellään vielä yksityiskohtaisemmin tutkimuksen lähtökohdat.

Markkinoinnin tai myynnin alalla ei ole suomenkielistä vertaisarvioitua tiedelehteä, minkä takia myyntiin keskittyvän vertaisarvioidun tutkimuksen julkaiseminen suomeksi on hyvin harvinaista, toteavat kirjan toimittajat jälkipuheessa. On hienoa, että arvostettu tiedekustantaja on ottanut tällaisen kirjan ohjelmaansa. Toisaalta tässä piilee myös eräs kirjan heikkouksista: sen luvut on kirjoitettu liiaksi tutkimusartikkelin mallin mukaisesti, ei niinkään yhtenäisen kirjan luvuiksi. Tästä seuraa turhaa toistoa ja metatekstiä, joka pitkästyttää lukijaa ja saa odottamaan, että kirjassa päästäisiin asiaan eli tuloksiin ja jonkin uuden äärelle. Eri luvuissa toistellaan, kuinka poikkeuksellisia aineistoja niissä käytetään ja miten erikoislaatuisesta tutkimusasetelmasta ja -teemasta on kyse. Tähän nähden tulokset jäävät melko vaatimattomiksi.

Lukukokemuksessani kirja muuttuu sitä mielenkiintoisemmaksi, mitä pidemmälle teos etenee. Tämä on tietenkin lukijalle palkitsevaa, mutta samalla on vaara, että kirja jää kesken - jos oletetaan, että joku muukin lukee vielä kokonaisia kirjoja kuin arvioija. Lisäksi kaikkia käsitteitä ei avata loogisessa järjestyksessä. Esimerkiksi niinkin keskeiset käsitteet kuin arvomyynti ja arvolupaus vilahtelevat tekstissä esipuheesta alkaen, mutta lukijalle ne avataan vasta kuudennessa luvussa, jonka otsikko on Arvolupauksen yhteistuottaminen: yhteisymmärryksestä asiakastarpeen kirkastamiseen.

Oma lukijan positioni ei sijoitu myynnin ja markkinoinnin alalle vaan sosiologisempaan työelämän tutkimukseen. Tästä näkökulmasta teoksen luvut keskustelevat turhan kapeasti oman alansa kirjallisuuden kanssa. Kirjassa esimerkiksi todetaan, että "aiempi tutkimus tarjoaa vain vähän tietoa asiakkaiden negatiivisten tunteiden tai asenteiden hallinnasta" (s. 67). Sama näkemys toistuu vielä laajemmin seitsemännessä luvussa, joka keskittyy tunneälyyn myyntivuorovaikutuksessa. Näin kirjoittajat ohittavat laajan, 1980-luvulla alkaneen keskustelun emotionaalisesta työstä, jolla lyhyesti sanottuna tarkoitetaan palvelualojen työntekijöiltä edellytettyä toimintaa oman ja asiakkaiden tunnetilojen hallitsemiseksi ja muuttamiseksi. Lukijana olin äärimmäisen hämmästynyt siitä, että tunteiden hallintaa ja tunneälyä ei suhteutettu millään tapaa emotionaalisen työn käsitteellistykseen. 
Kaiken kaikkiaan kirja antaa hyvän kuvan ihmisten välisen vuorovaikutuksen monitahoisuudesta myös niin rajatussa ja ennalta määrätyssä tilanteessa kuin myyntineuvottelu. Suhtaudun hieman skeptisesti siihen, että teos voisi tarjota paljoakaan uutta myynnin alan ammattilaisille eli niille, joiden työ on kirjassa tarkastelun kohteena ja jotka siis tekevät jo kirjassa analysoitua työtä käytännössä. Sen sijaan teos sopii hyvin oppikirjaksi niille, jotka haluavat perehtyä sellaiseen myynnin ja markkinoinnin tuoreeseen tutkimukseen, joka on tehty perinteisestä poikkeavien menetelmällisten valintojen avulla.

\section{Kirjoittaja}

\section{Tuija Koivunen}

YTT, dos., yliopistonlehtori (ma.), Itä-Suomen yliopisto

sähköposti: tuija.koivunen@uef.fi

twitter: @tuija_koivunen 